\title{
Improving Mathematics Learning Result By Applying The Discovery Learning Model And The Utilization of ICT- Based Multimedian
}

\section{Desy Haryani Handresmawati}

\author{
SD Negeri Kedalon 01 \\ dessyyani966@gmail.com
}

\section{Article History}

accepted $14 / 11 / 2020$

\begin{abstract}
The purpose of this study was to improve student learning outcomes in mathematics muple class III elementary school with discovery learning model using ICT-based multimedia. The research conducted was a Classroom Action Research (PTK) in three cycles. In the first cycle, students who completed the evaluation were $52 \%$. In the second cycle, students who completed after evaluating wre $76 \%$. In cycle III the students who completed after carrying out the post test were $94 \%$. These results indicate that the discovery learning model with the use of ICT-based multimedia can improve student learning outcomes, especially Class III mathematics muple at SDN Kedalon 01, Batangan District, Pati Regency.

Keywords: learning outcomes, discovery learning, use of multimedia, mathematics
\end{abstract}

\begin{abstract}
Abstrak
Tujuan dari penelitian ini adalah untuk meningkatkan hasil belajar peserta didik pada mupel matematika di sekolah dasar kelas III dengan model pembelajaran discovery learning dengan pemanfaatan multimedia berbasis TIK. Penelitian yang dilakukan adalah Penelitian Tindakan Kelas (PTK) sebanyak tiga siklus. Tahapan setiap siklusnya adalah perencanaan, pelaksanaan, observasi dan refleksi. Pada siklus I peserta didik yang tuntas setelah melaksanakan evaluasi sebesar 52\%. Pada siklus II peserta didik yang tuntas setelah melaksanakan evaluasi sebesar $76 \%$. Pada siklus III peserta didik yang tuntas setelah melaksanakan post test sebesar $94 \%$. Hasil ini menunjukan bahwa model pembelajaran discovery learning dengan pemanfaatan multimedia berbasis TIK dapat meningkatkan hasil belajar peserta didik khususnya mupel matematika Kelas III di SDN Kedalon 01 Kecamatan Batangan Kabupaten Pati.
\end{abstract}

Kata kunci: hasil belajar, discovery learning, pemanfaatan multimedia, matematika

Social, Humanities, and Education Studies (SHEs): Conference Series https://jurnal.uns.ac.id/shes

p-ISSN 2620-9284

e-ISSN 2620-9292 


\section{PENDAHULUAN}

Masa Pandemi Corona Virus 19 (Covid-19) ini membuat proses pembelajaran yang biasanya dilaksanakan dengan tatap muka di depan kelas, tidak dapat dilaksanakan lagi, hal ini karena adanya kekhawatiran semakin menyebarnya Covid19. Perlunya alternatif pembelajaran untuk menunjang kualitas pembelajaran yang baik demi keberlangsungan pendidikan. Masalah yang baru pun muncul, selain bagaimana melaksanakan pembelajaran jarak jauh tetapi juga bagimana cara guru tetap melakukan proses pembelajaran yang baik selama pandemi. Guru harus memastikan kegiatan belajar mengajar tetap berjalan, meskipun siswa berada di rumah. Semua muatan pelajaran disampaikan pada siswa dengan menggunakan bantuan teknologi. Muatan pelajaran Matematika tentu saja tidak luput dari hal itu. Padahal, mata pelajaran yang satu ini membutuhkan penjelasan dan pemahaman yang lebih mendalam. Banyak pilihan ide-ide pembelajaran yang bisa diterapkan dengan bantuan teknologi, memanfaatkan multimedia pembelajaran daring berbasis TIK. Perpaduan pembelajaran daring dan media pembelajaran berbasis TIK, merupakan perpaduan yang pas agar siswa dapat belajar secara online yang dapat diakses kapan saja dan di mana saja.

Menurut Sudjana (2016:3) "hasil belajar adalah perubahan tingkah laku setelah melalui proses pembelajaran yang mencakup bidang kognitif, afektif dan psikomotorik".

Berlandaskan Hosnan (2014:282), discovery learning adalah model pengembangan kemampuan belajar aktif pada siswa agar bisa investigasi dan mendapatkan ilmu secara mandiri. Dengan belajar aktif ini siswa juga bisa dilatih berpikir secara analisis dan problem solving sehingga ilmu pengetahuan bisa bertahan lama dalam diri siswa. Menurut Jerome Bruner dalam buku Djamarah (2002:22 (Adapun 6 langkah secara berurutan dalam pembelajaran model discovery learning dimulai dari pemberian rangsangan (stimulation), pernyataan/Identifikasi masalah (problem statement), pengumpulan data (data collection), pengolahan data (data processing), pembuktian (verification), menarik simpulan/generalisasi (generalization).

Ismail dkk dalam bukunya memberikan definisi hakekat matematika adalah ilmu yang membahas angka- angka dan perhitungannya, membahas masalah- masalah numerik, mengenai kuantitas dan besaran, mempelajari hubungan pola, bentuk dan struktur, sarana berpikir, maupun system, struktur dan alat (Ali Hamzah dan Muhlisrarini, 2013: 48)

Dalam modul Pembelajaran di SD Berbasis TIK (2019) disebutkan bahwa Teknologi Informasi Komunikasi (TIK) merupakan suatu program sebagai alat bantu untuk memanipulasi dan menyampaikan informasi. Secara umum, TIK mencakup dua aspek yakni teknologi informasi dan teknologi komunikasi. Teknologi informasi meliputi segala hal yang berkaitan dengan proses, penggunaan, manipulasi, dan pengelolaan informasi, sedangkan teknologi komunikasi meliputi segala hal yang berkaitan dengan penggunaan alat bantu untuk memproses dan mentransfer data dari perangkat yang satu ke perangkat lainnya. Dengan demikian, TIK mencakup semua teknologi yang dapat digunakan untuk menyimpan, mengolah, menampilkan, dan menyampaikan informasi dalam proses komunikasi.

Dalam pembelajaran Matematika khususnya pada materi perkalian dua bilangan cacah, peserta didik diberikan suatu permasalahan matematika, peserta didik diberikan keluasan untuk menyelesaikan masalah tersebut dengan pemahaman mereka terlebih dahulu. Sehingga dengan seperti itu peserta didik dapat membangun pengetahuan sendiri dari penyelesaian masalah tersebut. 
Perkalian dua bilangan cacah merupakan materi yang sangat penting karena pengetahuan dasar yang harus dmilik peserta didik untuk pembelajaran selanjutya yaitu pembagian. Pembelajaran perkalian dua bilangan cacah juga sangat berkaitan dengan kehidupan sehari-hari peserta didik. Untuk itu guru harus mampu melakukan pembelajaran yang sesuai dengan karakteristik dan materi yang akan disampaikan. Selain itu, muatan pelajaran matematika membutuhkan pemahaman dan latihan yang lebih mendalam. Banyak pilihan ide-ide pembelajaran yang bisa diterapkan salah satunya menggunakan model pembelajaran discovery learning dengan memanfaatkan multimedia pembelajaran daring berbasis TIK. Perpaduan antara model pembelajaran discovery learning dan media pembelajaran berbasis TIK dalam pembelajaran daring, merupakan perpaduan yang pas agar siswa dapat belajar secara online yang dapat diakses kapan saja dan di mana saja. Dengan perpaduan model pembelajaran discovery learning dan pemanfaatan TIK sebagai alat media pembelajaran berbentuk file slide Power Point, gambar, dan video pembelajaran. Di mana dalam pelaksanaannya nanti pembelajaran akan dilakukan secara daring melalui aplikasi WhatssApp Group dan Zoom meeting.

\section{METODE}

Penelitian ini adalah penelitian tindakan kelas (Classroom Action Research) dengan menerapkan model pembelajaran discovery learning dengan memanfaatkan multimedia yang berbasis TIK. Menurut Menurut Hopkins (1993), penelitian tindakan kelas diawali dengan perencanaan tindakan (Planning), penerapan tindakan (action), mengobservasi dan mengevaluasi proses dan hasil tindakan (Observation and evaluation).Sedangkan prosedur kerja dalam penelitian tindakan kelas terdiri atas empat komponen, yaitu perencanaan (planning), pelaksanaan (acting), pengamatan (observing), dan refleksi (reflecting), dan seterusnya sampai perbaikan atau peningkatan yang diharapkan tercapai (kriteria keberhasilan). Analisis penelitian ini adalah analisis deskriptif kuantitafif dimana dalam penelitian ini menyajikan hasil berupa data maupun angka. Penelitian ini dilaksanakan pada peserta didik kelas III SD Negeri Kedalon 01 Tahun Pelajaran 2020/2021 selama tiga siklus secara daring menggunakan aplikasi Zoom meeting dengan tiga siklus. Siklus I dilaksanakan pada tanggal 2 November 2020. Siklus II dilaksanakan pada tanggal 9 November 2020. Siklus III dilaksanakan pada tanggal 20 November 2020.Teknik pengumpulan data yang dilakukan dengan tes menggunakan googleform untuk mengetahui hasil belajar siswa.

\section{HASIL DAN PEMBAHASAN}

Pada observasi awal pelaksanaan pembelajaran daring, hasil belajar peserta didik masih rendah pada muatan pelajaran Matematika. Kriteria Ketuntasan Minimal (KKM) yang ditetapkan sekolah yaitu 65. Dari 17 peserta didik hanya 6 peserta didik yang tuntas dan 11 peserta didik yang belum tuntas. Artinya hanya 35\% peserta didik yang dapat memenuhi nilai KKM, sedang $65 \%$ peserta didik belum memenuhi KKM yang telah ditetapkan sekolah. Sehingga penulis perlu melakukan perbaikan pembelajaran matematika dengan menggunakan model pembelajaran discovery learning dengan memanfaatkan multimedia yang berbasis TIK, dengan harapan meningkatnya hasil belajar peserta didik dalam pembelajaran daring.

Pada siklus I pembelajaran dilaksanakan pada tanggal 2 November 2020. Dalam pelaksanaan tindakan perbaikan pembelajaran siklus I, penulis menggunakan model pembelajaran discovery learning dengan memanfaatkan multimedia berbasis TIK. Pembelajaran dengan model discovery learning dilaksanakan dalam 6 langkah secara berurutan mulai dari pemberian rangsangan (stimulation), 
pernyataan/Identifikasi masalah (problem statement), pengumpulan data (data collection), pengolahan data (data processing), pembuktian (verification), menarik simpulan/generalisasi (generalization). Berikut ini adalah hasil belajar peserta didik pada siklus I yang bisa dilihat pada tabel rentang nilai berikut.

Tabel1. Rentang Nilai Hasil Pembelajaran Siklus I

\begin{tabular}{llc}
\hline No & \multicolumn{1}{c}{ Rentang Nilai } & Frekuensi \\
\hline 1. & $0-20$ & 0 \\
2. & $21-40$ & 3 \\
3. & $41-60$ & 5 \\
4. & $61-80$ & 7 \\
5. & $81-100$ & 2 \\
& Jumlah & 17 \\
\hline
\end{tabular}

Berdasarkan analisis nilai siklus I yang dilampirkan pada tabel diatas, dapat kita lihat peserta didik yang mencapai $\mathrm{KKM}$ atau mendapat nilai diatas 65 sebanyak 9 peserta didik atau 52\% dari 17 peserta didik, sedangkan peserta didik yang tidak mencapai KKM atau mendapat nilai kurang dari 65 sebanyak 8 peserta didik atau $48 \%$ dari 17 peserta didik.

Setelah melaksanakan refleksi pada siklus I maka diputuskan untuk melanjutkan ke siklus II dikarenakan belum mencapai ketuntasan klasikal yang diharapkan. Pembelajaran siklus II dilaksanakan seperti siklus I. Pembelajaran siklus II dilaksanakan pada tanggal 9 November 2020. Berikut ini adalah hasil belajar peserta didik pada siklus II yang bisa dilihat pada tabel rentang nilai berikut.

Tabel 2. Rentang Nilai Hasil Pembelajaran Siklus II

\begin{tabular}{llc}
\hline No & Rentang Nilai & Frekuensi \\
\hline 1. & $0-20$ & 0 \\
2. & $21-40$ & 2 \\
3. & $41-60$ & 2 \\
4. & $61-80$ & 4 \\
5. & $81-100$ & 9 \\
& Jumlah & 17 \\
\hline
\end{tabular}

Berdasarkan analisis nilai siklus II yang dilampirkan dapat kita lihat peserta didik yang mencapai KKM atau mendapat nilai diatas 65 sebanyak 13 peserta didik atau $76 \%$ dari 17 peserta didik, sedangkan peserta didik yang tidak mencapai KKM atau mendapat nilai kurang dari 65 sebanyak 4 peserta didik atau $24 \%$ dari 17 peserta didik.

Setelah melaksanakan refleksi pada siklus II maka diputuskan untuk melanjutkan ke siklus III dengan tujuan untuk memantapkan hasil belajar peserta didik. Karena pada pembelajaran siklus II sudah mencapai ketuntasan klasikal yang diharapkan. Pembelajaran pada siklus III dilaksanakan seperti siklus-siklus sebelumnya. Berikut ini adalah hasil belajar peserta didik pada siklus III yang bisa dilihat pada tabel rentang nilai berikut. 
Tabel 3. Rentang Nilai Hasil Pembelajaran Siklus III

\begin{tabular}{llc}
\hline No & Rentang Nilai & Frekuensi \\
\hline 1. & $0-20$ & 0 \\
2. & $21-40$ & 0 \\
3. & $41-60$ & 2 \\
4. & $61-80$ & 5 \\
5. & $81-100$ & 10 \\
& Jumlah & 17 \\
\hline
\end{tabular}

Berdasarkan analisis nilai siklus III yang dilampirkan dapat kita lihat peserta didik yang mencapai KKM atau mendapat nilai diatas 65 sebanyak 15 peserta didik atau $88 \%$ dari 17 peserta didik, sedangkan peserta didik yang tidak mencapai KKM atau mendapat nilai kurang dari 65 sebanyak 2 peserta didik atau 12\% dari 17 peserta didik.

Dari tiga siklus yang sudah dilaksanakan selama 3 pertemuan dapat dipastikan bahwa model pembelajaran discovery learning dapat meningkatkan hasil belajar peserta didik pada mupel matematika Kelas III di SD Negeri Kedalon 01. Berdasarkan penuturan Suherman, dkk (2001:179) dengan model discovery learning siswa akan menguasai pelajaran secara mendalam. Ini dikarenakan siswa mencerna dan menemukan sendiri ilmu pengetahuan itu sehingga bisa lebih bertahan lama dalam ingatannya. Dengan menguasai pelajaran sendiri, maka hasil belajar siswa terhadap mupel matematika akan meningkat.

\section{SIMPULAN}

Berdasarkan hasil penelitian tindakan kelas yang telah dilaksanakan tiga siklus dapat disimpulkan bahwa penggunaan model pembelajaran discovery learning dengan pemanfaatan multimedia berbasis TIK dalam pembelajaran matematika kompetensi dasar menyatakan suatu bilangan sebagai jumlah, selisih, hasil kali atau hasil bagi dua bilangan cacah terhadap peserta didik kelas III Sekolah Dasar Negeri Kedalon 01 Kecamatan Batangan Kabupaten Pati dapat meningkatkan hasil belajar peserta didik. Hal tersebut terlihat dari aktivitas peserta didik dalam proses pembelajaran yang semakin meningkat dalam setiap siklusnya. Peserta didik akan selalu teringat akan materi yang diajarkan dikarenakan mereka menemukan dan membangun sendiri pengetahuan mereka pada saat menyelesaikan suatu permasalahan matematika. Serta pemanfaatan multimedia berbasis TIK sangat mendukung sekali untuk digunakan dalam menyampaikan pembelajaran dimasa pandemi seperti ini.

\section{DAFTAR PUSTAKA}

Hamzah, Ali dan Muhlisrarini. 2013. Perencanaan dan Strategi Pembelajaran Matematika.(Jakarta:Raja Grafindo Persada).

Djamarah Syaiful Bahri. 2002. Strategi Belajar Mengajar. Jakarta : Rineka Cipta

Hosnan, M. 2014. Pendekatan Saintifik dan Kontekstual dalam Pembelajaran Abad 21. Bogor: Ghalia Indonesia. 
SHEs: Conference Series 3 (3) (2020) 838- 843

Lestari, Ria. 2011. Pemanfaatan Media Pembelajaran Berbasis Teknologi Informasi dan Komunikasi Melalui Program Microsoft Power Point untuk Meningkatkan Minat Belajar Matematika Siswa (PTK di SMP Negeri 2 Jatirogo). Skripsi. Surakarta:

Universitas Muhammadiyah Surakarta. Tersedia pada laman http://eprints.ums.ac.id/11608/1/Halmuk.pdf (20 Oktober 2020)

Sudjana, N. 2009. Penilaian Hasil Proses Belajar Mengajar (Cetakan Ketigabelas). Bandung: PT Remaja Rosdakarya.

Suherman, Erman dkk. 2001. Strategi Pembelajaran Matematika Kontemporer. Bandung: Jica. 